УДК [377-043.86:057.34]:37.091.312

DOI: https://doi.org/10.35387/od.2(16).2019.76-84

Калюжна Тетяна Григорівна - кандидат фрілософрських наук, старший науковий співробітник, провідний науковий співробітник відділу андрагогіки Інституту педагогічної освіти і освіти дорослих імені Івана Зязюна НАПН України

ORCID ID: https://orcid.org/0000-0003-3118-2575

E-mail:tt-dd-kk@ukr.net

\title{
ПРОФЕСІЙНИЙ РОЗВИТОК ДЕРЖАВНИХ СЛУЖБОВЦІВ ЗАСОБАМИ ТРЕНІНГОВИХ ТЕХНОЛОГІЙ
}

Анотація. Стаття присвячена проблемі профресійного розвитку державних службовців засобами тренінгових технологій. Проаналізовано визначення терміну «профресійний розвиток державних службовців» українськими та зарубіжними науковцями, зроблено узагальнення даного терміну та відмічено, що професійний розвиток державних службовців це $\epsilon$ організований системний процес безперервного навчання державних службовців, спрямований на досягнення відповідного рівня профресіоналізму, саморозвитку, що сприятиме ефрективному та відповідальному виконанню посадових обов'язків, успішній реалізації внутрішньої та зовнішньої політики держави. Розкрито важливість профресійного розвитку державних службовців для формування високопрофресійного інституту державної служби в Україні та його ефективного функціонування у державі для забезпечення конкурентоспроможності на ринку праці, оновлення і зростання обсягів надання послуг, підвищення довіри суспільства та громадськості.

Особливу увагу приділено тренінговим технологіям для досягнення відповідних умінь і навичок, високого рівня профресійного розвитку державних службовців. Відмічено, що треніне $\epsilon$ творчим навчальним процесом, і його проведення залежить не тільки від вибору методів проведення тренінгових технологій, а й від особистості тренера, який повинен володіти високими особистісними моральними якостями та професійними навичками проведення тренінгу. Розглянуто методи тренінгових технологій такі як: метод мозкового итурму, метод Case Study, метод рольової гри, при застосуванні яких підвищується рівень професійного розвитку державних службовців. Наголошено на важливості використання тренінгових технологій насамперед у підвищенні рівня профресійного розвитку державних службовців, а також у системі післядипломної освіти, у системі підготовки, перепідготовки та підвищенні кваліфрікації державних службовців.

Ключові слова: професійний розвиток, державні службовці, треніне, інноваційні технології, методи, вибір методів навчання. 
Kaluzhna Tatiana - Candidate of Philosophy, Senior Researcher, Leading Researcher of the Andragogy Department of Ivan Ziaziun Institute of Pedagogical and Adult Education of the NAES of Ukraine

ORCID ID: https://orcid.org/0000-0003-3118-2575

E-mail:tt-dd-kk@ukr.net

\title{
PROFESSIONAL DEVELOPMENT OF CIVIL SERVANTS BY MEANS OF TRAINING TECHNOLOGIES
}

\begin{abstract}
The article is devoted to the problem of professional development of civil servants by means of training technologies. The definition of the term "professional development of civil servants» made by Ukrainian and foreign scientists is analyzed; generalization of this term is made, and it is noted that the professional development of civil servants is an organized systematic process of continuous training of civil servants, aimed at achieving the appropriate level of professionalism, and self-development providing effective and responsible performance of official duties as well as successful implementation of the state's domestic and foreign policy. There has been revealed the importance of professional development of civil servants for the formation of a highly professional institution of civil service in Ukraine and its effective functioning in the state for ensuring competitiveness in the labor market, updating and increasing the level of services, improving public and community confidence.

Particular attention has been paid to the training technologies that help achieve appropriate skills and high level of professional development of civil servants. It is noted that training is a creative learning process, and its implementation depends not only on the choice of training technologies of methods, but also on the personality of the trainer, who should possess high personal moral qualities and professional skills of conducting the training. It was considered methods of training technologies such as: brainstorming method, Case Study method, role-playing method, the application of which increases the level of professional development of civil servants. The importance of using training technologies is emphasized, first of all, in improving the professional development of civil servants, as well as in the system of postgraduate education, and in the system of training, retraining and professional development of civil servants.
\end{abstract}

Key words: professional development, civil servants, training, innovative technologies, methods, choice of teaching methods.

Постановка проблеми, їі актуальність. Приєднання України, як i більшості країн-членів ООН, до глобального процесу забезпечення сталого розвитку, зумовило виконання завдань та цілей - «забезпечення всеохоплюючої і справедливої якісної освіти та заохочення можливості навчання впродовж усього життя для всіх». Важливим стратегічним напрямом розвитку України відповідно до Стратегії сталого розвитку 
«Україна - 2020» та Стратегії реформування державного управління України на період до 2021 року, визначено модернізацію державної служби на засадах європейських принципів, які висуваються до країн-кандидатів на вступ до ЄС.

Виклики сьогодення вимагають формування високопрофесійного інституту державної служби в Україні, забезпечення умов його ефективного функціонування завдяки кваліфікованому персоналу, здатному належно проводити політику держави, вчасно реагувати на трансформаційні виклики. Саме тому дедалі більшої актуальності набуває дослідження сучасних тенденцій управління професійним розвитком державних службовців і, відповідно, удосконалення системи професійного навчання державних службовців в Україні.

Проблема професійного розвитку персоналу органів державної влади, забезпечення ефективності функціонування навчальних закладів, які входять до інституціональної системи професійного розвитку персоналу в Україні набула надзвичайного значення з прийняттям Закону України «Про державну службу» № 889-VIII від 10 грудня 2015 року, Закону України «Про освіту» № 2145- VIII від 9 вересня 2017 року, а також, на їх виконання, Концепції реформування системи професійного навчання державних службовців, голів місцевих держадміністрацій, їх перших заступників та заступників, посадових осіб місцевого самоврядування та депутатів місцевих рад, схваленої Розпорядженням Кабінету Міністрів України № 974-р від 1 грудня 2017 року.

Аналіз останніх наукових досліджень і публікацій. Особливості професійного розвитку державних службовців розглянуто у працях В. Богатирець, В. Гриньової, Н. Гончарук, М. Новікова, Є. Краснякова, О. Оболенського, О. Окіс, В. Олуйко, Л. Пуховської, С. Хаджирадєвої, М. Салун, С. Серьогіна, В.Ягупова, а також зарубіжних: Томаса Н. Гаравана, С. Борковської, Д. Боссарт, К. Деммке, О. Кузнєцова, М. Мазурик, В. Урбаняк, А. Філак, Л. Швєтліковскі, Дж. Ягільскі.

Аналіз і узагальнення наукових досліджень уможливило висновок про те, що проблемі професійного розвитку державних службовців засобами тренінгових технологій приділено недостатньо уваги.

Мета статті - проаналізувати термін «професійний розвиток державних службовців» та розкрити важливість використання тренінгових технологій, сучасних методик підготовки, перепідготовки та підвищення кваліфікації для досягнення високого рівня профресійного розвитку державних службовців.

Виклад основного матеріалу дослідження. Професійний розвиток державних службовців - багатогранне та складне поняття, яке охоплює широке коло взаємозв'язаних психологічних, педагогічних, соціальних та економічних проблем.

У сучасній літературі професійний розвиток розглядається як основний результат навчання, який визначають, як:

- системно-організований процес безперервного професійного 
навчання персоналу для підготовки його до виконання нових виробничих функцій, професійно-кваліфікаційного просування, формування резерву керівників та вдосконалення структури персоналу;

- забезпечення і організацію процесу навчання для досягнення поставлених організацією цілей;

- удосконалення навичок та вмінь, розширення обсягу знань, підвищення компетенції, схильності до навчання і ентузіазму співробітників на всіх рівнях організації, що сприяє безперервному зростанню (Гриньова, 2012, 228 с.).

Томас Н. Гараван розглядає професійний розвиток державних службовців як цілеспрямований комплекс інформаційних, освітніх та прив'язаних до конкретних робочих місць елементів, які сприяють підвищенню кваліфікації персоналу організації відповідно до завдань розвитку самої організації та потенціалу її співробітників (Thomas $\mathrm{N}$. Garavan, 1995, c. 343).

Зокрема поняття професійного розвитку державних службовців ширше розглядає А. Кібанов. Науковець визначає професійний розвиток державних службовців як сукупність організаційно-економічних заходів служби управління персоналом у сфері навчання співробітників організації, їх перепідготовки і підвищення кваліфікації. Ці заходи охоплюють питання професійної адаптації, оцінювання кандидатів на вакантну посаду, поточної періодичної оцінки кадрів, планування ділової кар'єри та службово-професійного просування кадрів, роботи з кадровим резервом (Кибанов, 2018, с.86-95).

За В. Ягуповим професійний розвиток державного службовця - це мета, смисл і цінність його професійної культури як особистості та як конкретного фахівця; складний, суперечливий і багатогранний процес, який складається 3 особистісного, професійного та фахового розвитку, детермінований, як правило, соціальними, професійно-технологічними, віковими, особистісними, провідними індивідуально-психічними, професійно важливими та фаховими якостями та рисами, має відкритий, нерівномірний і гетерохронний характер; результат постійного пошуку відповіді щодо сутності суперечностей (зовнішні та внутрішньо особистісні), які постійно виникають у професійній діяльності, та намагання фахівця їх вирішити або зняти; необхідна умова успішної професійної діяльності фахівця; необхідна умова особистісної та професійної самоактуалізації фахівця в професійній і фаховій діяльності (Ягупов, 2015, с. 126-136).

Виходячи із аналізу сучасних поглядів науковців, можна стверджувати, що професійний розвиток державних службовців - це системно організований процес безперервного професійного навчання персоналу для підготовки його до виконання нових адміністративних функцій та професійно-кваліфікаційного вдосконалення, а також це безперервний, цілеспрямований, свідомий процес особистісного та професійного зростання фахівця, який заснований на отриманні нових знань, вмінь та навичок. 
Світовий досвід показує, що одним з найбільш ефективних методів особистісно-професійного розвитку $є$ тренінг. Причому, для державних службовців це має бути тренінг акмеологічний, спрямований на досягнення вищого ступеня індивідуального розвитку шляхом системного застосування активних засобів групової та індивідуальної роботи. Такі засоби загалом мають забезпечити всебічний розвиток особистості державного службовця, формування та постійне збагачення ділових якостей, професійних знань, навиків і вмінь, які необхідні для ефективного виконання посадових фуннкцій.

Особливостями тренінгу в сучасному суспільстві є його експансія не тільки на різні види професійної діяльності, але й на різні види колективних та індивідуальних проблем і потреб. Тренінги стають все більш технологічними, включають у себе передові досягнення методології, педагогіки, психології та інших наук. Вони характеризуються значною різноманітністю.

Основою процесу пізнання в тренінгу є активна позиція учасників, коли вони можуть ставити питання, висловлювати свою думку. Тренінгове заняття має бути організоване так, щоб відбувалося безперервне цікаве спілкування, обмін досвідом, отримання задоволення від нових відкриттів. Тренер повинен діяти в теплій щирій манері, створювати в групі позитивний зворотній зв'язок і проявляти здатність швидко реагувати на нестандартні ситуації, бути коментатором і експертом, допомагаючи учасникам об'єктивно оцінювати свою поведінку, впливати на складні поведінкові реакції.

Тренінги дозволяють отримати не просто теоретичні знання, а перш за все навички (компетенції), які можна буде використовувати на практиці. Тому, важливе завдання в процесі проведення тренінгу $\epsilon$ створення атмосфери навчання для всіх учасників заходу, де вони будуть отримувати необхідні уміння і навички для успішної роботи на державній службі. Для цього тренеру необхідно використовувати найбільш ефективні техніки комунікації. У цьому процесі, особливе значення має створення творчої атмосфери і взаємна повага, як з боку учасників тренінгу, так i самого тренера. Потрібно пам'ятати, що тренінг $є$ творчим процесом. Саме в цьому процесі величезна роль відводиться особистості самого тренера, а саме його знанням, обраній методиці проведення тренінгу, досвіду, позитивному настрою і впевненості в собі у будь-яких ситуаціях.

Охарактеризуємо складові, що впливають на поведінку учасників тренінгу. Так, під час тренінгу виробляються конкретні навички (компетенції), які безпосередньо впливають на переконання, почуття і думки державного службовця, що і сприяє засвоєнню нової інформації. Саме тому, тренер повинен знати і чітко усвідомлювати взаємовплив i взаємозв'язок складових тренінгу. Тут велику роль відіграє професіоналізм тренера. Наступними складовими тренінгового заняття $€$ структура тренінгу, здібності учасників, рівень володіння професійними навичками, мотивація, індивідуальні особливості державного службовця, стиль 
навчання. Знаючи, який стиль навчання підходить слухачеві, можна правильно вибудувати план його професійного розвитку (Солдатов, 2016, c. 257).

Особливу роль в процесі проведення тренінгу для державних службовців мають рольові ігри та вправи, метою яких $є$ розвиток та відпрацювання нових умінь і навичок. Існує величезна кількість методик, ігор і вправ, націлених на вміння вирішувати проблеми, виходити зі складних ситуацій, розвивати навички критичного мислення, вибирати правильний варіант поведінки державного службовця. Розглянемо деякі 3 них.

Вправа - це активність учасників, яка організована певним чином і працює на поетапне освоєння нових навичок. Вправами зазвичай називають системні дії, націлені на розвиток у державних службовців організаційних, управлінських, емоційних та інших професійних навичок, чому мають сприяти певні умови. Форми вправ можуть бути різними, але всі вони зазвичай будуються за певними правилами, яких необхідно дотримуватися учасникам тренінгу. Під час обговорення необхідно уникати суперечок та поважати думки кожного.

Рольова гра - складна системна інтерактивна техніка, у процесі застосування якої використовується рольова структура ведення заняття, тобто певний набір ролей, які регламентують діяльність і поведінку його учасників. Організаційною одиницею рольової гри виступає умовна проблемна ситуація, при вирішенні якої у державних службовців підвищується комунікативна компетенція. Умовна проблемна ситуація розгортається у процесі заняття як окремий сюжет. В основу може бути покладена навчальна або реальна управлінська (професійна) проблема, формування якої містить відповідне питання (або серію питань). Протягом гри тренер визначає смислову лінію аналізу теоретичної проблеми або управлінської ситуації, порушує чи ставить додаткові запитання і завдання. Він заохочує до гри всіх присутніх в атмосфері доброзичливості, взаємодопомоги, рівноправності. Тренер завершує заняття підведенням підсумків, наголошуючи на змісті та реалізації мети.

Case Study. Метод «ситуаційних досліджень» (case study) став надзвичайно поширеним в 70-80-і роки XX століття. Він з'явився в Школі бізнесу Гарвардского університету (вперше в 1924 році). Кейс-технологія як навчальний метод використовується для того, щоб задіяти комунікативні та творчі здібності державних службовців, навчити їх здобувати знання та сфрормувати компетентності. Метод полягає в використанні конкретних випадків (ситуацій, історій, тексти яких називаються «кейсом») для спільного аналізу, обговорення або вироблення учасниками рішень 3 певної проблеми.

Кейси (ситуаційні вправи) мають чітко виражений характер і мету. Як правило, вони пов'язані з проблемою або ситуацією, яка існувала, чи і існує на даний момент. Це завжди моделювання життєвої ситуації, і те рішення, що запропонує учасник кейса, може служити як відображенням 
рівня компетентності і професіоналізму державного службовця, так і реальним рішенням проблеми.

У кейс-технології не даються конкретні відповіді, їх необхідно знаходити самостійно. Це дозволяє, спираючись на власний досвід, формулювати висновки, застосовувати на практиці одержані знання, мати власний (або груповий) погляд на проблему. В кейсі проблема представлена в неявному, схованому вигляді, як правило, вона не має однозначного вирішення.

Мозковий штурм - груповий метод роботи, в процесі якого відбувається народження нових ідей і розвивається творче мислення учасників тренінгу. У цьому процесі всі учасники тренінгу діляться на групи і кожна працює окремо. У процесі такої роботи відбувається народження нових оригінальних ідей для розв'язання складної проблеми (як оптимально спланувати і побудувати траєкторію професійного розвитку і кар'єрного росту сучасного державного службовця, як розкрити власний професійний, діловий і особистісний потенціал, як зуміти регулювати, контролювати й моделювати власну життєдіяльність і професійну поведінку тощо). Для більш ефективних результатів тренінгу, тренер може використовувати різні інноваційні технології, які сприятимуть досягненню поставленої мети.

Ефективне завершення тренінгу відіграє величезну роль і здатне посилити вплив на засвоєння відповідних компетенцій. В кінці тренінгу учасникам надається можливість оцінити його. Для цього використовується опитувальник або анкета, які заповнюються учасниками тренінгу. Опитувальник або анкета повинні охопити всі сторони процесу. Це необхідно тренеру для того, щоб проаналізувати оцінки учасників і зрозуміти чи були досягнуті цілі, наскільки ефективно проходила робота, де і які моменти тренінгу потрібно доопрацювати, на яких ключових моментах потрібно було більш детально зупинитися і т. п.. Тому необхідно складати структуру тренінгів через систему спостережуваних і необхідних навичок і поведінки державних службовців. Важливо враховувати, що тренінг - це ретельно продуманий, спроектований, з урахуванням десятків і сотень найважливіших принципів і критеріїв, цілісний навчальний процес.

Тренінгові технології набувають неабиякої популярності в Україні, зокрема, відповідно до Концепції Української школи урядування (УШУ), прийнятої НАДС 17 вересня 2019 р., створений тренінговий центр, який забезпечує підвищення кваліфікації державних службовців за загальними, спеціальними професійними (сертифікатними) та короткостроковими програмами у межах виконання державного замовлення НАДС на підвищення кваліфікації державних службовців за визначеними напрямами. (Деякі питання Всеукраїнського центру підвищення кваліфікації державних службовців і посадових осіб місцевого самоврядування: наказ НАДС від 21 лютого 2019 р. № 29-19).

Висновки. Особливістю стану сучасної державної служби нашої країни $є$ ускладнення характеру діяльності в умовах постійно зростаючих 
політичних, економічних і соціальних проблем, очікування суспільства від державних службовців високого ступеня відповідальності, професіоналізму, оперативності, порядності і непідкупності. За таких умов підвищується значимість регулярної підготовки, перепідготовки та підвищення кваліфікації державних службовців, в основі навчання яких повинні лежати програми і форми професійної підготовки, зокрема тренінгові технології, націлені на професійний розвиток, розвиток впевненості у своїх можливостях, процес самопізнання, саморозвитку і самореалізації.

Перспективними напрямами подальших досліджень є вивчення проблем професійного розвитку державних службовців шляхом використання тренінгових технологій, сучасних методик підготовки, перепідготовки та підвищення кваліфікації, аналізу накопиченого вітчизняного та зарубіжного досвіду у цій сфері.

\section{Список використаних джерел}

Ващенко, К. (2017). Професійна підготовка державних службовців: теорія, методологія, практика. Івано-Франківськ: Місто НВ. 416.

Гриньова, В. (2012). Адміністративне управління трудовим потенціалом. Харків: ХНЕУ. 228.

Деякі питання Всеукраїнського центру підвищення кваліфікації державних службовців і посадових осіб місцевого самоврядування: наказ НАДС від 21 лютого 2019 р. №29-19. URL: https://usg.org.ua/concept-ukra-nsku-shkolu-uryadu/

Кибанов, А. (2018). Управление персоналом: М.: КНОРУС. 202.

Солдатов, А. (2016) Я - бизнес-тренер. Секреты обучения взрослой аудитории. Москва: Альпина Паблишер, 257.

Ягупов, В. (2015) Методологічні засади професійного розвитку особистості фахівця. 126-136. URL: http://lib.iitta.gov.ua/10784/.

Thomas N., Garavan, (1995). Pat Costine, and Noreen Heraty Training and Development: Concepts, Attitudes, and Issues. Training and Development in Ireland. Cengage Learning EMEA. 643.

\section{References (translated and transliterated)}

Vashchenko, K. (2017) Training of civil servants: theory, methodology, practice. Ivano-Frankivsk: Misto NV. 228 s. (in Ukrainian)

Hrynova, V. (2012). Administrative management of labor potential. Kharkiv: KhNEU. 228. (in Ukrainian)

Some Issues of the All-Ukrainian Center for Advanced Training of Civil Servants and Officials of Local Self-Government: nakaz NADS vid 21 liutoho 2019 r. № 29-19 Rezhym dostupu: https://usg.org.ua/concept-ukra-nsku-shkoluuryadu/ (in Ukrainian)

Kibanov, A. (2018) Personnel Management: Moskva: KNORUS. 202. (in Russian)

Soldatov, A. (2016). I am a business coach. Secrets of teaching an adult audience. Moskva: Al pina Pablisher. 257. (in Russian)

lahupov, V. (2015). Methodological principles of professional development of the 
personality of the specialist. 126-136. Rezhym dostupu: http://lib.iitta.gov.ua/10784/ (in Ukrainian)

Thomas N. Garavan, (1995) Pat Costine, and Noreen Heraty Training and Development: Concepts, Attitudes, and Issues. Training and Development in Ireland. Cengage Learning EMEA. 643.

\section{УДК 378:7.012}

DOI: https://doi.org/10.35387/od.2(16).2019.84-91

Кирилова Олександра Сергї̈вна - аспірантка Київської державної академії декоративно-прикладного мистецтва і дизайну імені Михайла Бойчука

ORCID ID: https://orcid.org/0000-0001-7124-2996

E-mail: veratraduzione@gmail.com

\section{ПІДГОТОВКА МАЙБУТНІХ ДИЗАЙНЕРІВ ДО ЗАСТОСУВАННЯ АРТПЕДАГОГІЧНИХ ТЕХНОЛОГІЙ У ПРОФЕСІЙНІЙ ДІЯЛЬНОСТІ ЯК НАУКОВА ПРОБЛЕМА}

Анотація. У публікації автором здійснено аналіз проблеми підготовки майбутніх дизайнерів до застосування артпедагогічних технологій у професійній діяльності як науково-теоретичної проблеми. Доведено, що незважаючи на наявність численних наукових розвідок з проблем окремих питань артпедагогіки, здебільшого ці наукові розвідки не висвітлюють підготовку майбутніх дизайнерів у закладах вищої мистецької освіти до застосування артпедагогічних технологій у профресійній діяльності, а виокремлюють ї̈ фоорми, принципи та методи, як корекційні соціально-педагогічні, психологічні технології, техніки та тренінги. Уточнено сутність поняття «артпедагогічна технологія» в контексті вищої мистецької освіти. Виокремлено основні напрями діяльності у підготовці майбутніх дизайнерів інтер'єрів до застосування артепедагогічних технологій у професійній діяльності (аромотерапія, вивчення і аналіз творів мистецтв, виконання спеціальних вправ і завдань, застосування кіно-, відео- та музичних фррагментів тощо). Визначено, що артпедагогічна технологія - це комплексна інтегративна система засобів художньої діяльності (заходів психолого-педагогічної діяльності), зміст якої охоплює інтеграцію мистецтва, культурології, педагогіки, психології, фрізіології з метою профресійного самовдосконалення, розвитку профресійно важливих якостей особистості. Водночас артпедагогічні технології являють собою комплекс форм, методів та засобів організації роботи студентів над певними проектами. Визначено, що мистецький аспект в артпедагогічній технології $\epsilon$ засобом професіоналізації особистості; виконує здоров'язеберігаючу фрункцію; забезпечує розвиток творчих здібностей та потенціалу тощо. Доведено, що проблема підготовки майбутніх дизайнерів у закладах вищої мистецької освіти до 